Eastern Illinois University

From the SelectedWorks of Lee E. Patterson

2017

Minority Religions in the Sasanian Empire: Suppression, Integration and Relations with Rome

Lee E. Patterson

Available at: https://works.bepress.com/lee_patterson/12/ 


\title{
8 Minority Religions in the Sasanian Empire: Suppression, Integration and Relations with Rome
}

\author{
Lee E. Patterson
}

Gauging the importance of religion to the exercise of political will in the Sasanian world requires enormous care. It is all too easy to take the Great Kings at their word as they championed the doctrines of Zoroastrianism in their political pronouncements, especially as some of them also persecuted Christianity. Whether or not such sentiments were genuine, a closer analysis of the evidence suggests a more pragmatic royal use of religion. The political realities on the ground were more often the deciding factor in how the kings related to the religious sectors of Sasanian society. This state of affairs sometimes set the kings against the Zoroastrian clerics, whose agendas were not always in alignment, and it explains why Christian persecutions were usually motivated more by politics than doctrine. Moreover, this dynamic also explains the prominence of the Christian church in the later Sasanian period as kings employed it as a base of support, much as they had the Zoroastrian hierarchy.

\section{INTRODUCTION}

The complexities of religious life in the Sasanian realm, especially at the levels of the political elite, are staggering. No less so are the varied scholarly interpretations of how religion functioned in the state, especially religion's influence on the foreign and domestic policies of the shahanshahs, which is the primary concern of the present chapter. One basic fact has long been accepted: although Zoroastrianism was prominent in the Sasanian Empire, it was in fact a vast and diverse empire of many traditions existing in a coherent, 
if not always harmonious, system. The fortunes of these traditions, including Christianity, Judaism, Manichaeism, Buddhism and so on, fluctuated with the temperaments and policies of each shahanshah and, to a lesser extent, other entities such as powerful Zoroastrian mobads. Less universally but still commonly argued is another proposition: while religion ostensibly explains the policies of the kings, who usually claim to uphold some sort of Zoroastrian principle, such as orderliness and truth $(a s h a)$, the actual motivations are more often than not informed by the political realities on the ground.

This framework is our starting point, but my purpose is to place greater emphasis on the latter proposition, with two main arguments: first, it is the king, not the priest, who should be our focus. For example, even if we acknowledge a mobad as the architect of a Christian persecution, motivated by genuine religious sentiment, the policy serves the political purposes of the king, who might publicly extol the religious virtues of the persecution but in reality regard it as necessary to achieve an immediate political goal. The same applies to policies that followed the opposite path and promoted Christianity (and other non-Zoroastrian traditions). Very often this political goal involved attaining leverage on the Romans, whose presence on the Sasanian western frontier required constant vigilance by the shahanshabs. Thus, the position of the king in relation to both internal sectors, such as priests and nobility, and external ones, such as the Romans, depended on political calculations that employed religion to achieve desired outcomes. I am consequently arguing for stronger and more centralised royal control than some others have, ${ }^{\mathrm{I}}$ partly on the basis of the archaeological record. ${ }^{2}$

The second argument involves how we might more precisely gauge the relationship of kingship and religion in the Sasanian world. That there was an interdependence cannot be denied. But where do we draw the line? Do we deny the close relationship of king and cleric and attribute it to later literary invention, as Gignoux, or embrace it as fundamental to Sasanian royal ideology, as Shaked, who further holds that this ideology required royal control over religious doctrine and practices? ${ }^{3}$ I believe the answer lies in between these views. The close relationship of kingship and religion was real but not as later sources depicted it. Whatever religious sentiments any individual Sasanian king may have held - something as impossible to determine as with Constantine - Realpolitik should be seen as the fundamental determining factor in the pursuit of Sasanian policy, even when outwardly expressed as the enforcement of a religious doctrine. Thus, for example, the Christianisation of Armenia became 
a concern for the shahanshahs more for its political and strategic consequences than for any doctrinal implications. Religion, however, was the medium through which their policies were given expression, whether or not they felt their official acts also to be pious, and thus control of the religious hierarchies, mainly Zoroastrian and eventually Christian as well, was fundamental to their method.

Aside from the difficulties of our sources, of which space only allows a brief treatment here, we must confront a number of factors that enhance the challenges of the present exercise. They can be listed succinctly as follows: (I) 'policies' determined by individual shahanshahs; (2) relations between Romans and Sasanians (diplomatic, military and economic); (3) relations between Sasanian kings and Zoroastrian priests; (4) uncertainties about the cohesion of a Zoroastrian 'church'; (5) relations between Sasanian kings and Persian Christians; and (6) relations between Persian Christians and 'Orthodox' Christians in the Roman Empire. A corollary of numbers (3) and (4) is the fact that Zoroastrianism, and particularly its theology, was not a monolithic phenomenon but probably took on different forms at the hands of the kings, the priests and the general populace. This fact is fundamental to understanding the relationship of the king and the mobads. The brands of Zoroastrianism employed may have reflected not only different world views - for example, a purer Avestan ideology versus a mindset that acknowledges the multicultural realities on the ground - but also the sometimes competing interests of the kings and the priests.

\section{THE KING AND ZOROASTRIANISM}

A quick look at some of the primary evidence, putting aside late or post-Sasanian material for the moment, reveals how ardently the shahanshahs outwardly embraced Zoroastrian doctrine and employed it to cast their policies, achievements and even political position in the appropriate light. The founder Ardashir made clear in his reliefs, most famously at Naqsh-e Rostam, ${ }^{4}$ that his rise to power was in accordance with the divine plan of Ohrmazd (Ahura Mazda), from whom he claimed his right to rule over Eranshahr. Ardashir is shown receiving an emblem of power from Ohrmazd while his horse tramples the Arsacid king Artabanus IV, which parallels Ohrmazd's horse trampling Ahriman. In his trilingual inscription from the same location (SKZ), Ardashir's son Shapur I describes himself as a 'Mazda-worshipping' king who has expanded his rule not only by conquest but by the establishment of sacred 
fires. The name Eranshahr also had important religious implications, traceable to the Avesta, which added to the legitimacy of the new regime. ${ }^{5}$ In his inscription Shapur also cast relations with Rome in Zoroastrian terms when he said that the emperor (probably Philip the Arab) 'lied and did wrong to Armenia', ${ }^{6}$ aligning the Romans with the Lie/Chaos $(d r u \gamma)$ and the Sasanians with the Truth/Order (asha). 'Mazda-worshipping' also appears on the coins of Ardashir and Shapur, as well as depictions of the fires. In the fifth century, beginning with the coinage of Yazdgerd II, a shift occurred with the removal of shahanshah Eran and the addition of kay, harking back to the mythical period of the Kayanid kings of the Avesta, which reinforced Yazdgerd's pro-Zoroastrian agenda that would be felt especially acutely in Armenia. ${ }^{8}$ A relief from the late period, at Taq-e Bostan, shows Ohrmazd and possibly Anahita investing Khusro II (or possibly Peroz). ${ }^{9}$

Once we get past these public declarations, the situation becomes less simple, partly because of what was happening on the ground and partly due to historiographical issues arising from later Pahlavi, Syriac and Arabic sources. Source interpretation has contributed to an assumption that the royal court and the Zoroastrian hierarchy were, as the Testament of Ardashir claims, 'twins', that is to say, working together as a cohesive whole. We find similar attestations in the Denkard ${ }^{\mathrm{IO}}$ and the Letter of Tansar. ${ }^{\mathrm{II}}$ All these sources are late or post-Sasanian, but they probably preserve earlier material. The key point here is that most of this material 'came down to us through the channel of the Zoroastrian priesthood'. ${ }^{\text {I2 }}$ Shaked's point is essential for understanding the kings' religious policy. The relationship that these sources celebrate was often in reality more antagonistic, primarily because of the kings' policy of blunting any clerical attempt to curb their power. Thus the union claimed by the sources is merely a 'literary theme', a different sort from the association actually employed by the kings, an alliance of king and cleric formed by the former on their terms. ${ }^{13}$ In some cases, there may also have been a corresponding aversion to embracing Zoroastrianism, or rather the mobads' version of it. If there were in fact at least two strands of Zoroastrianism, one royal and one clerical, we should not be surprised. Even as the religious eclecticism of the Sasanian realm has long been recognised, there is increasing acknowledgement now of the same dynamic within Zoroastrianism itself. ${ }^{I 4} \mathrm{We}$ might quickly illustrate this point by considering Shapur I's apparent embrace of Manichaeism.

The status of Mani in Shapur's court has complicated assessments 
of Shapur's religiosity. Even as he ostensibly espoused Zoroastrianism in his inscriptions, his religious leanings were clearly eclectic. We have an interesting note in the Denkard that Shapur was drawn to sources of knowledge beyond Mazdean doctrines. ${ }^{15}$ This inquisitiveness probably attracted Shapur to Mani's teachings, which claimed to be a 'reformed Zoroastrianism'. ${ }^{16}$ As such Shapur may have seen Manichaeism as an alternative to the more orthodox version. This is mostly supposition, as we cannot know exactly how Shapur perceived Manichaeism or why he found it so attractive, but we must remember, as noted above, that our notions of Zoroastrianism may not match how the Sasanians perceived it. ${ }^{17}$ Mani's doctrines may have represented a radical departure from Mazdean tradition, and certainly Kirdir's main interest during and after Shapur's time was to codify and unify Zoroastrianism and tie it more to the state, whereas Manichaeism was more universal in its outlook. But it is possible Shapur understood Manichaeism to be another version of Zoroastrianism.

Still another variant to the orthodoxy of Kirdir and other clerics was the cult of Anahita that the Sasanian royal family maintained at Estakhr. Or at least we can regard this as a variant in the sense that this was more of a family cult than a state religion. Anahita was a water goddess to whom the early Sasanians dedicated the heads of their defeated foes. ${ }^{18}$ This shrine was the centre from which Ardashir's father Papak had built his power locally in Fars. ${ }^{19}$ This reality stands in contrast to the tradition in the Denkard that Ardashir restored the religion of Ahura Mazda after the dark interlude that had begun with Alexander the Great, and that his mobad Tansar had gathered the fragments of the Avesta. Tansar's historicity has been questioned, especially as Shapur's Res Gestae makes no mention of him. Indeed, Kirdir himself is hardly prominent in Shapur's inscriptions despite his claims in his own later texts that he held supreme authority over Zoroastrians in the empire..$^{20}$ Interestingly, this particular divergence in the Zoroastrian tradition took a dramatic turn when the end of Kirdir's supremacy was effectively announced by Ardashir's grandson Narseh through the promotion of Anahita in his Paikuli inscription. ${ }^{21}$

As the cult of Anahita supported Papak and his son's bid for local supremacy in the final years of the Arsacid period, in their claim to be shahanshah Ardashir and his successors likewise made astute use of an elaborate religious apparatus. On the practical side this apparatus provided important mechanisms for administering the empire (see next section). No less important were the kings' ideological 
needs, namely Zoroastrian and later Christian support of the idea of royal supremacy. By way of the renewed Zoroastrian tradition, as Daryaee has noted, the kings managed to cultivate a sense of sacredness and the idea that they were vital to the well-being of the empire. This was achieved in part through their claim of descent from the gods, as in the legends on Ardashir's coins: shahan shah eran ke cibr az yazdan, 'King of Kings of Eran (Iranians), whose lineage (is) from the gods'. This meant that Ardashir had either elevated his putative ancestor Sasan to divine status or claimed a connection to the gods, the yazatas, or both. The claim of a connection to the gods is a specifically Iranian rendering of an old Hellenistic concept going back to Alexander the Great, when royal claims of divine descent were common. ${ }^{22}$ The strategy of the later kings, beginning with Yazdgerd II (438-57), changed with the introduction of kay into the royal titulature, which connected the kings to the Kayanids of the Avesta. The timing is suggestive: an association with and possible emulation of legendary kings who fought foes in the east as the Sasanians began to confront new dangers on their eastern frontier in the fifth century, with the use of 'Eranshahr' to extend their claim further eastward. ${ }^{23}$

\section{RELIGIOUS ADMINISTRATION OF THE EMPIRE}

Just as religion promoted royal legitimacy, centralisation of Sasanian administration strengthened the kings' control of the empire, improving on the Arsacid system of vassal kings. This entailed, for example, the eradication, within the first century of Sasanian rule, of the vassal kings, who were replaced by royal princes and later by marzpans; central control of numismatic iconography, an essential propagandistic tool given that coins were an important medium of contact between ruler and subject; and the issuing of royal seals. ${ }^{24}$ Other archaeological evidence also reinforces the view of a strong central authority commanding significant resources, with the cooperation of the nobility, which does not always match the characterisation of those who feel the kings were generally weak in the face of recurring noble opposition, as suggested particularly by literary sources. ${ }^{25}$ This evidence includes fortresses and fortifications (e.g. the Gorgan Wall), elaborate irrigation systems (e.g. in Mesopotamia and Azerbaijan), and enhanced urbanisation efforts (e.g. Ardashir Khurrah in Fars and Eyvan-e Karkha in Khuzestan). ${ }^{26}$

The multicultural nature of the empire also came to enhance the status of the kings, not only through legitimisation but in adminis- 
tration. At the centre of the elaborate bureaucracy was the king, who exerted control through his relationships with the various groups in power, notably the religious hierarchies who had the training to oversee political, economic and judicial affairs. This power dynamic, widely recognised by scholars, is important for understanding the role of religion in the Sasanian realm, at least as the shahanshabs saw it. ${ }^{27}$ From such late sources as Ferdowsi's Shahnama, supported by Syriac martyrologies along with seals issued by mobads and other officials (also attested by Agathias ${ }^{28}$ ), we learn that Zoroastrian clerics presided over law courts, supervised state finances (including taxation), participated in military campaigns, supervised districts, served as diplomatic emissaries to foreign powers, and so on. ${ }^{29}$ From the early fifth century, as we shall see, Christian authorities began to take on some of these responsibilities as well. ${ }^{30}$ In the late period, according to the Sasanian law book Madiyan-e hazar dadistan, the mobadan mobad even issued decrees in his own name, with his own seal, and clearly wielded power comparable to that of the king. ${ }^{3}$ In fact an elaborate hierarchy seems to have developed around the mobadan mobad, with structures comparable, in Gignoux's mind, to those in the western and eastern Christian churches. ${ }^{32}$

This religious bureaucracy has been interpreted by some as the formation of an organised Zoroastrian church, especially during the dramatic periods of Kirdir (third century) and Mihr Narseh (fifth century). The trend now is to reject this interpretation of the evidence. ${ }^{33}$ These controversies have little bearing on the basic argument presented here, that is, the importance of the religious hierarchy, however organised, for royal administration. It bears noting, however, that the apparent free reign granted to Kirdir and Mihr Narseh reminds us that the Zoroastrian clerics had their own agenda, which did not always align with that of the kings. Even the apparent congruence in the outlook of Mihr Narseh and Yazdgerd II does not negate the king's political motivations for the spread of Zoroastrianism (see below).

\section{THE KING AND CHRISTIANITY: ADMINISTRATION}

A wide spectrum exists in the scholarship on Persian Christianity in terms of how harmoniously it existed in the Sasanian Empire. A proper starting point for understanding the relationship of the shahanshabs and the Christians is the proposition that persecutions were the exception, not the rule, and that their motivations were 
political. The politics in question involved both domestic affairs, especially the security of the king's position, and foreign, especially relations with the Romans. These persecutions tended to be aimed at elite Christians, whose activities had greater economic and political consequences for the Sasanians. This state of affairs was largely the work of the kings themselves, who began to include Christians in the running of the empire, supplementing the work done by the Mazdean hierarchy.

The Christian presence in Mesopotamia had been steadily growing for centuries, with penetration east of the Tigris perhaps as early as the second century and other movement deeper into Parthian/ Persian territory. A major contributing factor to the initial rise of this population was the deportations of Christians by Shapur I after his sack of Antioch and other places in Syria and Cappadocia. ${ }^{34}$ By the fifth century, Christianity had made deep inroads into Sasanian society, as attested by frequent Iranian names of clergy and lay officials in official church documents. ${ }^{35}$ By the sixth century, if not before, Christians had joined the ranks of the Sasanian aristocracy, along with other newcomers such as the dehkans. ${ }^{36}$

More work is still required for a better understanding of how integrated Christians were into Sasanian society, but it seems certain that to some extent Christians experienced an awkward existence in the Sasanian world, partly because of doctrinal differences with Zoroastrianism over treatment of the dead, laws concerning marriage, and so on. Still, as Rist has argued, Christians by and large managed to balance their loyalty to the shahanshah and their religious duty. While some of the persecutions resulted from hiccups when Christians fell short of adhering to the former, this state of affairs was not the norm. ${ }^{37}$ The material record, moreover, affirms a certain measure of cultural assimilation, as well as an orientation away from Roman Christianity, in theological, liturgical and ideological terms. Such a picture emerges from Stefan Hauser's analysis of the remains of churches (e.g. those at Qasr Serij, Veh Ardashir and Qusair), along with grave styles, as well as seals and other materials, when we see, for instance, Persian Christians eschewing Byzantine architectural styles and depictions of human figures. ${ }^{38}$

Given the enormous presence Christianity came to have, we should not be surprised that the shahanshahs saw an opportunity to employ the services of bishops and other officials, especially when it helped to counterbalance the influence of the Zoroastrian hierarchy. Already in the fourth century, bishops were collecting taxes among the Christian communities of Mesopotamia and Khuzestan for the 
Sasanian authorities, as we know, for instance, from the East Syriac accounts of the beginning of Shapur II's persecution, which we will deal with more directly below. According to these accounts, the failure of Simeon, bishop of Seleucia-Ctesiphon, to collect a special double tax on the king's Christian subjects led to Simeon's arrest around 340, the matter having some urgency because of the need for revenue in Shapur's Roman wars. Simeon's role in raising revenue was especially important given the primitive status of Sasanian finances in this period, but it anticipates the enhanced role bishops would have in the fiscal and administrative operations of the provinces later. ${ }^{39}$

This enhanced role properly begins with the official organisation of the Church of the East at the Synod of Ctesiphon in 4IO, presided over by Yazdgerd I, where its structure, procedures and doctrines (including the Nicene Creed) were established. ${ }^{40}$ This vitally important development came in a period of, and was partly influenced by, détente between the Romans and the Sasanians. Yazdgerd himself, despite a persecution at the end of his reign (see below), was known for his friendly attitude towards Christianity. Indeed, for this reason, he was described in later sources, including the Shahnama and the Arab historians Balkhi, Tha'alibi and Tabari, as being hostile to the mobads, earning him the moniker 'the sinner'. ${ }^{4}$ Yazdgerd's good relations with Theodosius II, meanwhile, were fostered by the diplomatic efforts of Marutha, bishop of Sophanene. Indeed, the synod happened because Marutha convinced Yazdgerd to recognise Ishaq, bishop of Seleucia-Ctesiphon, as catholicos, or head of the church..$^{42}$ In fact, the primacy of this bishopric served Yazdgerd's purposes. Significantly, the acts of this synod, compiled in the eighth century by the patriarch Timothy I in the Synodicon Orientale, draw parallels between Yazdgerd and Constantine. The implication is clear: both leaders sought to enhance their political status by claiming leadership of a powerful religious institution and, no less important, assert universal rule, an interesting appropriation of a Roman claim that may have contributed to the persecutions of Shapur II. ${ }^{43}$ Yazdgerd reserved the right to nominate the catholicos and through him exert control of a significant religious apparatus that could reinforce the king's legitimacy among Christians and perform advisory, diplomatic and administrative functions. ${ }^{44}$

In a sense the Church of the East became an even more Persian institution with the schism from the Byzantine church at the Synod of 424 and the embrace of Nestorianism by 484 , at the Synod of Beth Lapat. The former meant that the Persian catholicos no longer looked to the Byzantine church for consultation and derived his 
authority strictly from Christ alone. These developments helped to allay the concerns of most of the shahanshahs that Persian Christians might potentially align themselves with the Romans and undermine the Sasanian state. ${ }^{45}$

\section{THE KING AND CHRISTIANITY: PERSECUTION}

This state of affairs, however, did not stop persecutions from occurring in the later period. Indeed, the question becomes how we reconcile the increasing reliance on Christian authorities for administration with the periodic persecutions of the fifth to the seventh centuries. Richard Payne challenges the orthodoxy by arguing that the Syriac hagiographers have exaggerated the extent of persecution for the sake of their religious agendas, the reality lying in the realm of pragmatism, as noted in the case of Simeon above. ${ }^{46}$ For me pragmatism does indeed help to reconcile the paradox, for the kings only persecuted when it was in their immediate political interests to do. Sometimes this meant bowing to clerical pressure, as with Yazdgerd I, who reversed his stance on Christianity when violence against fire temples forced him to persecute. He was left with no choice, given that the fire temples were important for the functioning of the state as they formed part of the economic and social power of the aristocracy. ${ }^{47}$ Likewise, in his dealings with the catholicos Mar Aba, Khusro I had to walk a fine line. On the one hand, Khusro made significant use of the church hierarchy, personally liked Aba, and sought to protect him from the Mazdean clerics. However, Aba was accused of collaborating with the Romans, an accusation that could not be taken lightly given the war that had started in 540. Thus in $542 \mathrm{Aba}$ was removed from office, though he was only exiled rather than killed..$^{8}$

Already near the beginning of the Sasanian engagement with Christians, royal motivation lay in politics. We noted Shapur I's deportations of Christians from sacked Roman cities above, but it bears noting that these moves were not made out of any religious hostility to Christians. For Shapur, these deportees were sources of excellent labour to develop newly founded cities, such as Gondeshapur in Khuzestan and Bishapur in Fars. In fact, according to the Chronicle of Seert, ${ }^{49}$ Christians in these areas thrived on the lands given to them to develop..$^{50}$

Constantine's conversion to Christianity overshadows most discussions of the first major sequence of persecutions, conducted by Shapur II from c. 340 to the end of his reign in 379 . With Christianity now embraced by the Roman Empire, the fear was that Persian Christians 
might constitute a fifth column in the Sasanian realm. ${ }^{5 \mathrm{I}}$ There are many uncertainties about whether Constantine's letter to Shapur II, recorded by Eusebius, ${ }^{52}$ is genuine; ${ }^{53}$ whether Shapur received it or any other communication articulating Constantine's claim to protect all Christians in the world; and, if so, what the king would have made of it. ${ }^{54}$ But whether or not Shapur's concern of a Christian menace in his empire can be traced at all to any correspondence with Constantine, many scholars, as far back as Christensen, recognise that Shapur's concern was not religious or doctrinal but political. To start with, his religious leanings seemed not very anchored, as he re-established the family cult of Anahita in Estakhr and possibly embraced Zurvanism in addition to championing the official Mazdean orthodoxy. Additionally, the 'great persecution' seemed not to apply to the Jewish elements in the Sasanian world. ${ }^{55}$

We noted earlier that Shapur turned against the Christians upon the refusal of Bishop Simeon to collect a special tax for the state. In about 340, Simeon was arrested, and it is likely that the persecutions were limited at this point. Decret has noted a synchronism in 344 between Simeon's execution and Constantius' capture of Singara, an unfortunate (for the Sasanians) development in the continuing drama of the Roman frontier. Decret suggests that the former was partly motivated by the latter and that at this point Shapur stepped up the persecutions. ${ }^{56}$ To this we might add another bit of evidence for the political dimension of the 'great persecution'. The anxiety Shapur felt about Christianity can be measured especially by the strategic implications of not only Constantine's conversion but that of Tiridates IV of Armenia in 3I4. That Armenia should officially become Christian was troubling mainly because such a transformation aligned it with the Romans even more than before. ${ }^{57}$ The importance of Armenia to Shapur is amply demonstrated in his response to Constantius' offer of peace in 356: among the most important terms Shapur insisted on was the restoration of Armenia and other territories taken in the Treaty of Nisibis, which was forced upon Narseh in 298 and which Shapur now described, in Ammianus' rendering, as a composita fraude.$^{5^{8}}$ The recovery of Armenia was a high priority for Shapur, and this state of affairs provides the proper context in which to assess the 'great persecution'. Because of Shapur's anti-Christian stance, as Decret has observed, the conflict with Rome 'took on the appearance of a war of religions' ('prenait l'allure d'une guerre de religions') (my emphasis). ${ }^{59}$

I believe the same dynamic is in play in the massive effort by Yazdgerd II to promote Zoroastrianism in the Sasanian realm as well as Armenia. The latter venture has made Yazdgerd one of the 
great villains in Armenian historiography, which lionised Vardan Mamikonean and other Armenian Christians who resisted the Sasanians' attempt to suppress Christianity in 45I. The architect of this endeavour was Yazdgerd's vizier (hazarbed), Mihr Narseh, a member of the powerful Suren clan who had also served Yazdgerd I and Bahram V. In addition to his religious and administrative duties Mihr Narseh served as a general. He was evidently an ardent partisan of the Zurvanite version of Zoroastrianism, which he tried to impose on the Armenians. ${ }^{60}$ As for Yazdgerd II, we have a curious paucity of coverage in the Arabic and Persian material, with emphasis on his personal piety and on tensions with the Persian nobility, ${ }^{6 \mathrm{I}}$ while the Armenian and Syriac sources make him into a religious zealot; this tradition has made its way into much modern scholarship, beginning with Labourt. ${ }^{62}$

But it is not Yazdgerd's religiosity that best explains his persecution of Christians and Jews in the empire. Control of Armenia continued to be important for securing the Roman frontier, but even more pressing for Yazdgerd was heightened internal instability, including strained relations with the nobility, and the changing situation in the east. We noted above the change in his royal titulature, with the addition of kay, invoking the legendary Avestan kings, the Kayanids, who also confronted great challenges in the east. By the fifth century that challenge was a formidable Hunnic confederation which inflicted a series of defeats on Yazdgerd at the beginning of his reign. It is significant that Yazdgerd's moves against the Christians did not begin until his eighth year. According to the Armenian chronicler Kazar P'arpets' $\mathrm{i}^{63}$ and the Syriac History of Karka de Beth Selok, Yazdgerd blamed the Christians for his defeats in the east, apparently because Armenian and Iberian nobles provided much of his cavalry. He began the persecutions by trying to force Christian nobles at Karka to convert to Zoroastrianism. Our main Armenian sources for the revolt of 45 I note that Yazdgerd made the same demands of the nobility in Armenia and Iberia. ${ }^{64}$ Indeed, of Yazdgerd's persecutions of non-Zoroastrians it is important to point out that they were in fact generally limited, with the noble ranks receiving the brunt, despite Mihr Narseh's poisonous rhetoric about the evils of Christianity. Yazdgerd's main purpose was to counter the internal and external pressures threatening the empire by enhancing royal centralisation in the administration, which required cooperation from the nobility. It was important to establish the terms on which the nobles and priests were to yield to royal authority. ${ }^{65}$ This is the reason why Yazdgerd eventually moderated his stance towards 
Armenia and through the new marzpan Atrormizd Arshakan (i.e. Adhur-Hormizd) allowed religious freedom there for the sake of stability, ${ }^{66}$ a position hardly compatible with one taken by a religious zealot. Zoroastrian belief, as McDonough points out, may have been a 'test of personal loyalty' for Yazdgerd, ${ }^{67}$ but I do not believe we are dealing with the same motives as in the case of Mihr Narseh.

\section{CONCLUSION}

We might conclude with an obversation has that lurked behind much of the foregoing discussion. The persecutions, especially when pursued by the shahanshahs, were usually aimed at a focused segment of the Christian populace: the nobility. And to be sure, both Mazdean mobads and Christian bishops generally hailed from this sector of society. Whether Zoroastrian or Christian, these officials were essential for the functioning and security of society and, just as important, for promotion of royal legitimacy. The case has been made, I hope, that while religion certainly played an important role in these matters, for the kings it was a means to an end. As a general rule, we may posit contrasting views and uses of Zoroastrianism between the kings and the clerics, the latter usually fostering more genuine religious concerns. Whatever personal piety the kings may have felt, their use of religion was informed by the realities arising from their relations with the nobility and from their relations (friendly and hostile) with the powers on their frontiers, especially the Roman. Both Zoroastrianism and Christianity served the kings well, and when they did not the kings took measures that one should hesitate to regard as indications of their religiosity.

\section{ABBREVIATIONS}

ANRm Relief of Ardashir I at Naqsh-e Rostam

DkM Denkard (ed. Madan)

KKZ Inscription of Kirdir from the Ka'be-ye Zardosht

PO Patrologia Orientalis

ŠKZ Inscription of Shapur I the from Ka'be-ye Zardosht

\section{NOTES}

I For example, Pourshariati 2008: 45 5-6; Rubin 2008: I 53-5.

2 See especially Payne 20I4.

3 Gignoux 1984; Shaked 1990: 263. 
$4 A N R m$ I

5 Wiesehöfer 200ı: I65-7; Gnoli I989: I37-9.

$6 \check{S} K Z$ iо.

7 Daryaee 2013: I6.

8 Shayegan 20I3: 808-9; Daryaee 20I3: I7.

9 Daryaee 2009: I06; Schippmann I990: 97.

Io E.g. $D k M 3.58$.

I I Gignoux I984: 72-6; Kreyenbroek 20I3: 20-2.

I 2 Shaked 2008: I05.

I3 Gignoux I984: 80; cf. Shaked I994: I I2-I3; Gnoli I989: I38 no. I3.

I4 Pourshariati 2008: 324-6; Gnoli I989: I67-74. In fact there was even greater complexity (the doctrine of Zurvanism comes to mind, for instance), as well as the likely condition that Zoroastrianism only penetrated upper levels of Sasanian society, with a freer flow of other traditions among the wider classes. 'One must assume that constant Zoroastrian references to the various strata of society that comprise the ordered, harmonious whole are mere wishful thinking' (Russell I986: I 28).

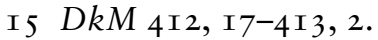

I6 Hutter I993: 6, cf. Duchesne-Guillemin r983: 879 .

I7 See further Kreyenbroek 2008: 7; Shaked 2008: I04.

I 8 Tabari, Ta'rikh I.8I9.

I9 Schippmann I990: 92-3.

20 Rubin 2008: I4O-I. This matter is uncertain. In his own inscription on the Ka'be-ye Zardosht, Kirdir claims to have had authority over all Zoroastrian officials and affairs throughout the empire in the time of Shapur $\left(K K Z_{\mathrm{I}-2}\right)$. But he only issued these inscriptions during the reign of Bahram II (27693), when Kirdir held significant power as a mobad. In Shapur's Res Gestae Kirdir is only listed as a herbed, following a lengthy roll of officials, with no indication of significant responsibility (ŠKZ 34 [Pers.], 28 [Parth.]). See further Kreyenbroek 2013: 28-30.

2I Daryaee 2009: I3.

22 Daryaee 2013: I3-I 5.

23 Shayegan 20I3: 807; Daryaee 20I3: I7.

24 McDonough 2005: I4I-69.

25 To be sure the 'strength' of the shahanshahs fluctuated over time, but the question becomes whether this at least partially results from historical circumstances rather than a structural flaw in the system that compromised the position of the kings. This of course is not the place to attempt a resolution, except where religion informs the matter. See further Payne 20I4: 4-5, contra Pourshariati 2008: 455-6; Rubin 2008: I 53-5.

26 Payne 20I4: 4-6.

27 Payne 20I 5: 4I; Shaked I994: I09-IO; McDonough 20I I: 298.

28 Agathias, Histories 2.26.5.

29 Shaked I990: 268-7I; Daryaee 2009: I 27-33.

30 Greatrex 2003: 80 .

3 I Shaked I990: 269; cf. Gignoux I984: 78.

32 Gignoux I983: $258-9$.

33 See, for example, Schippmann I990: 92-3; Rubin 2008: 140-4; Wiesehöfer 200I: 2I I-I3; Hauser 2008: 33 . 
34 Baum and Winkler 2003: 8-9; Hage I973: I74-5; cf. Brock I982: 3.

35 Asmussen r983: 942.

36 McDonough 20II: 307.

37 Rist I996: 4I-2.

38 Hauser 2007; 2008.

39 Payne 20I 5: 40-I.

40 In general see Labourt I904: 92-9; Wood 201 2: 58-62; Baum and Winkler 2003: I4-I7; Hage I973: I8I-2.

4I Pourshariati 2008: 66; Asmussen 1983: 939-40.

42 Blockley I992: 48-9; Wood 20I 2: 58-9. As Blockley has noted, Marutha's Persian diplomacy is well documented. For sources, see Blockley I992: 196 no. I9.

43 McDonough 2008: I30; Wood 201 2: 59; Decret I979: I 50.

44 McDonough 2011: 304-5; Wood 2012: 60.

45 Asmussen I983: 944-5; Greatrex 2003: 79-80; Hage I973: I83.

46 Payne 2015: 23-58.

47 McDonough 2008: I3 I-4; Payne 20I 5: 47-8.

48 Maksymiuk 2015: I26; Brock I982: 5.

$49 \mathrm{PO}_{4 \cdot 3}$, II: $220-3$.

50 Decret I979: I04-5, I I0; Rist I996: 26.

5 I Brock I982: 7-8; Alinia 2008: 53-4; Labourt I904: 44.

52 Eusebius, Vita Constantini 4.9-I3.

53 For a useful summary of the main arguments, see Frendo 2001.

54 Cf. Barnes I985: 136.

55 Christensen I944: 250; Duchesne-Guillemin I983: 886; Schippmann I990: 95 .

56 Decret 1979: 145-7.

57 Decret I979: I38-9; Rist I996: 30-I.

58 Ammianus Marcellinus $17 \cdot 5$.

59 Decret I979: 138-9.

60 Pourshariati 2008: 60-2; McDonough 2005: 75; Duchesne-Guillemin I983: 89I.

6I Pourshariati 2008: 70.

62 Labourt I904: I 26-30; Asmussen 1983: 942.

63 tazar $87=2.48$.

64 Łazar 43-4 = 2.2 I-2; Ełishē I7-I 8 pp.7I-2; McDonough 2006: 74; Rist I996: 34 .

65 McDonough 2006: 75-8I; Payne 20I 5: 45-6.

66 Łazar 73 = 2.40; Garsoïan 2004: 347 .

67 McDonough 2006: 8I.

\section{B I B LIO GR A P HY}

Alinia, S. (2008), 'Zoroastrianism and Christianity in the Sasanian Empire (Fourth Century AD)', in S. M. Reza Darbandi and A. Zournatzi (eds), Ancient Greece and Ancient Iran: Cross-Cultural Encounters, Athens: National Hellenic Research Foundation, pp. 53-8.

Asmussen, J. P. (1983), 'Christians in Iran', in E. Yarshater (ed.), The Cambridge 
History of Iran: The Seleucid, Parthian, and Sasanian Periods, 3.2, Cambridge: Cambridge University Press, pp.924-49.

Barnes, T. D. (I985), 'Constantine and the Christians of Persia', Journal of Roman Studies, 75, pp. I26-36.

Baum, W. and Winkler, D. W. (2003), The Church of the East: A Concise History, London: Routledge.

Blockley, R. C. (I992), East Roman Foreign Policy: Formation and Conduct from Diocletian to Anastasius, ARCA 30, Leeds: Francis Cairns.

Brock, S. P. (1982), 'Christians in the Sasanian Empire: A Case of Divided Loyalties', Studies in Church History, I8, pp. I-I9.

Christensen, A. (I 944), L'Iran sous les Sassanides, Copenhagen: E. Munksgaard. Daryaee, T. (2009), Sasanian Persia: The Rise and Fall of an Empire, London: I.B.Tauris.

Daryaee, T. (2013), 'Sasanian Kingship, Empire and Glory: Aspects of Iranian Imperium', in V. Naddaf, F. Goshtasb and M. Shokri-Foumeshi (eds), Ranjo-Ganj: Papers in Honour of Professor Z. Zarshenas, Tehran: Institute for Humanities and Cultural Studies, pp. I I-22.

Decret, F. (I 979), 'Les conséquences sur le christianisme en Perse de l'affrontement des empires romain et sassanide: de Shâpûr Ier à Yazdgard Ier', Recherches Augustiniennes, I4, pp.9I-I 52.

Duchesne-Guillemin, J. (I983), 'Zoroastrian Religion', in E. Yarshater (ed.), The Cambridge History of Iran: The Seleucid, Parthian, and Sasanian Periods, 3.2, Cambridge: Cambridge University Press, pp. 866-908.

Frendo, D. (200I), 'Constantine's Letter to Shapur II: Its Authenticity, Occasion, and Attendant Circumstances', Bulletin of the Asia Institute, I 5 , pp. 57-69.

Garsoïan, N. (2004), 'Frontier-Frontiers? Transcaucasia and Eastern Anatolia in the Pre-Islamic Period', in A. Carile (ed.), La Persia e Bisanzio: convegno internazionale (Roma, I4-I 8 ottobre 2002), Atti dei convegni Lincei 20I, Rome: Accademia nazionale dei Lincei, pp.327-52.

Gignoux, P. (I983), 'Die religiöse Administration in sasanidischer Zeit: Ein Überblick', in H. Koch and D. N. MacKenzie (eds), Kunst, Kultur und Geschichte der Achamenidenzeit und ihr Fortleben, Berlin: Reimer, pp. 253-66.

Gignoux, P. (1984), 'Church-State Relations in the Sasanian Period', Bulletin of the Middle Eastern Culture Center in Japan, I, pp.72-80.

Gnoli, G. (I989), The Idea of Iran: An Essay on Its Origin, Serie Orientale Roma LXII, Rome: Istituto Italiano per il Medio ed Estremo Oriente.

Greatrex, G. (2003), 'Khusro II and the Christians of His Empire', Journal of the Canadian Society for Syriac Studies, 3, pp.78-88.

Hage, W. (I973), 'Die oströmische Staatskirche und die Christenheit des Perserreiches', Zeitschrift für Kirchengeschichte, 84, pp. I74-87.

Hauser, S. R. (2007), 'Christliche Archäologie im Sasanidenreich: Grundlagen der Interpretation und Bestandsaufnahme der Evidenz', in A. Mustafa, J. Tubach and G. S. Vashalomidze (eds), Inkulturation des Christentums im Sasanidenreich, Wiesbaden: Reichert, pp.93-I36.

Hauser, S. R. (2008), “Die Christen vermehrten sich in Persien und bauten Kirchen und Klöster": Eine Archäologie des Christentums im Sasanidenreich', in U. Koenen and M. Müller-Wiener (eds), Grenzgänge im östlichen 
Mittelmeerraum: Byzanz und die islamische Welt vom 9. bis I3. Jahrhundert, Wiesbaden: Reichert, pp. 29-64.

Hutter, M. (I993), 'Manichaeism in the Early Sasanian Empire', Numen, 40.I, pp. 2-I 5 .

Kreyenbroek, P. G. (2008), 'How Pious was Shapur I? Religion, Church, and Propaganda under the Early Sasanians', in V. Sarkhosh Curtis and S. Stewart (eds), The Sasanian Era, Idea of Iran 3, London and New York: I.B. Tauris, pp.7-I 6 .

Kreyenbroek, P. G. (2013), 'Zoroastrianism under the Sasanians', in K. Rezania (ed.), Teachers and Teachings in the Good Religion: Opera Minora on Zoroastrianism, Wiesbaden: Harrassowitz, pp. I9-50.

Labourt, J. (I904), Le christianisme dans l'empire perse sous la dynastie sassanide (224-632), Paris: Lecoffre.

McDonough, S. (2005), 'Power By Negotiation: Institutional Reform in the Fifth Century Sasanian Empire', PhD thesis, UCLA.

McDonough, S. (2006), 'A Question of Faith? Persecution and Political Centralization in the Sasanian Empire of Yazdgard II (438-457 CE)', in H. A. Drake (ed.), Violence in Late Antiquity: Perceptions and Practices, Aldershot: Ashgate, pp.69-8I.

McDonough, S. (2008), 'A Second Constantine? The Sasanian King Yazdgard in Christian History and Historiography', Journal of Late Antiquity, I.I, pp. I 27-4I.

McDonough, S. (20II), 'The Legs of the Throne: Kings, Elites, and Subjects in Sasanian Iran', in J. P. Arnason and K. A. Raaflaub (eds), The Roman Empire in Context: Historical and Comparative Perspectives, Chichester: Wiley-Blackwell, pp.290-32 I.

Maksymiuk, K. (20I 5), 'Die Politik von Xusrō I. Anōššrvān (53 I-579) gegenüber Christen in dem Iran', Historia i Świat, 4, pp. I23-34.

Payne, R. E. (20I4), 'The Archaeology of Sasanian Politics', Journal of Ancient History, 2.2, pp. I-I3.

Payne, R. E. (2015), A State of Mixture: Christians, Zoroastrians, and Iranian Political Culture in Late Antiquity, Oakland: University of California Press.

Pourshariati, P. (2008), Decline and Fall of the Sasanian Empire: The SasanianParthian Confederacy and the Arab Conquest of Iran, London: I.B. Tauris.

Rist, J. (I996), 'Die Verfolgung der Christen im spätantiken Sasanidenreich: Ursachen, Verlauf und Folgen', Oriens Christianus, 80, pp. I7-42.

Rubin, Z. (2008), 'Persia and the Sasanian Monarchy (224-65I)', in J. Shepard (ed.), The Cambridge History of the Byzantine Empire: c.500-I492, Cambridge: Cambridge University Press, pp. I30-55.

Russell, J. R. (I986), 'Zoroastrianism as the State Religion of Ancient Iran', Journal of the K. R. Cama Oriental Institute, 53: 74-I42. (Reprinted in Russell, J. R., Armenian and Iranian Studies, HATS 9, Cambridge: Harvard University Press, 2004, pp.65-I33.)

Schippmann, K. (I990), Grundzüge der Geschichte des Sasanidischen Reiches, Darmstadt: Wissenschaftliche Buchgesellschaft.

Shaked, S. (I 990), 'Administrative Functions of Priests in the Sasanian Period', in G. Gnoli and A. Panaino (eds), Proceedings of the First European Conference of Iranian Studies, Held in Turin, September 7 th-I Ith, I987 by the Societas 
Iranologica Europea, part I, Rome: Istituto Italiano per il Medio ed Estremo Oriente, pp. 26I-73.

Shaked, S. (I 994), Dualism in Transformation: Varieties of Religion in Sasanian Iran, London: School of Oriental and African Studies, University of London. Shaked, S. (2008), 'Religion in the Late Sasanian Period: Eran, Aneran, and Other Religious Designations', in V. Sarkhosh Curtis and S. Stewart (eds), The Sasanian Era, Idea of Iran 3, London and New York: I.B. Tauris, pp. I03-I7. Shayegan, M. R. (2013), 'Sasanian Political Ideology', in D. T. Potts, The Oxford Handbook of Ancient Iran, Oxford: Oxford University Press, pp. 805-I3.

Wiesehöfer, J. (200I), Ancient Persia from 550 BC to 650 AD, London: I.B. Tauris.

Wood, P. (2012), 'Collaborators and Dissidents: Christians in Sasanian Iraq in the Early Fifth Century', in T. Bernheimer and A. Silverstein (eds), Late Antiquity: Eastern Perspectives, Exeter: Gibb Memorial Trust, pp. 57-70. 